\title{
IMPLEMENTASI NILAI KARAKTER NASIONALISME MELALUI PEMBELAJARAN SEJARAH MATERI PENDUDUKAN JEPANG DI INDONESIA DI SMA SWASTA BUDISATRYA MEDAN KELAS XI T.A 2018/2019
}

\author{
Oleh: \\ Arfan Diansyah \\ Maria Magdalena
}

\begin{abstract}
ABSTRAK
Penelitian ini bertujuan untuk mengkaji: (1) Implementasi nilai karakter Nasionalisme melalui pembelajaran sejarah materi "Pendudukan Jepang di Indonesia" di SMA Swasta Budisatrya Medan t.a 2018/2019, (2) Hasil dari implementasi nilai karakter nasionalisme di SMA Swasta Budisatrya Medan, (3) Kendala yang dihadapi guru dalam mengimplementasikan nilai karakter nasionalisme di SMA Swasta Budisatrya Medan. Jenis penelitian ini adalah penelitian kualitatif dengan menggunakan metode deskriptif kualitatif. Informan dalam penelitian ini adalah guru sejarah dan siswa siswi kelas XI di SMA Swasta Budisatrya Medan. Teknik pengumpulan data yang dilakukan dalam penelitian ini adalah observasi, wawancara, serta dokumentasi yang dilakukan didalam kelas pada saat pembelajaran berlangsung maupun diluar kelas. Adapun teknik analisis data yang dilakukan dalam penelitian menggunakan teori Miles dan Hubberman yang membagi teknik analisis data melalui 3 proses yaitu: reduksi data, penyajian data, dan verifikasi data (penarikan kesimpulan). Hasil dari penelitian ini adalah : (1) Guru Sejarah di SMA Swasta Budisatrya Medan telah mengimplementasikan nilai karakter nasionalisme lewat perencanaan pembelajaran yang disusun kedalam RPP serta telah melaksanakan kegiatan pembelajaran yang dapat membantu menumbuhkan nasionalisme dalam diri siswa/i, (2) Hasil implementasi tersebut dapat diketahui melalui kegiatan, respon, serta tingkah laku siswa selama melakukan proses pembelajaran khususnya pada saat belajar sejarah, serta aktivitas siswa yang dilakukan diluar jam belajar dalam kelas, (3) Kendala yang dihadapi guru dalam mengimplementasikan nilai karakter nasionalisme di SMA Swasta Budisatrya Medan meliputi: waktu, faktor lingkungan, serta media elektronik seperti televisi dan handphone.
\end{abstract}

Kata kunci : Nilai Karakter, Sejarah, Nasionalisme 


\section{PENDAHULUAN}

Pendidikan merupakan usaha yang dilakukan secara sadar, terencana, dan sistematis untuk mentransfer pengetahuan kepada orang lain. Pendidikan sangatlah penting bagi kehidupan manusia karena pendidikan merupakan salah satu kebutuhan dasar untuk mengembangkan semua potensi yang dimiliki manusia sebagai bekal hidup di kehidupan sekarang maupun kehidupan yang akan datang. Dengan demikian, pendidikan bertujuan untuk mengembangkan semua potensi yang dimiliki manusia. Hal ini sejalan dengan Undang-Undang RI No. 20 Tahun 2003 tentang SISDIKNAS Bab II Pasal 3 yang berbunyi: Tujuan pendidikan nasional ialah berkembangnya potensi peserta didik agar menjadi manusia-manusia yang beriman dan bertaqwa kepada Tuhan Yang Maha Esa, berakhlak mulia, sehat, berilmu, cakap, kreatif, mandiri dan menjadi warga negara yang demokratis serta bertanggung jawab.

Tujuan pendidikan nasional akan tercapai apabila ada kerjasama yang baik antara pemerintah, masyarakat, dan pelaku pendidikan. Selain dibutuhkan kerjasama yang baik, kualitas sumber daya manusia juga sangat berpengaruh terhadap tingkat pendidikan di suatu negara yang pada akhirnya akan mempengaruhi kualitas pendidikan di negara tersebut.

Kemajuan bidang pendidikan dapat dipantau dan dinilai melalui informasi yang beredar dalam kehidupan sehari - hari. Berita yang dilansir oleh surat kabar maupun media elektronik menunjukan banyak perilaku yang tidak terpuji dari generasi muda di negeri ini yang dapat menggambarkan bahwa pendidikan dianggap gagal menghasilkan manusia yang berakhlak. Budi pekerti, etika, dan moral mulai terabaikan. Ironisnya hal ini sudah merasuki kehidupan pelajar dan mahasiswa. Seperti siswa yang menunjukkan sikap kurang hormat kepada orang dewasa, kasus menyontek yang sudah menjadi kebiasaan, bullying yang dilakukan sekelompok orang (genk) untuk mengucilkan seseorang yang memiliki kelemahan fisik atau mental, serta penggunaan obat-obatan terlarang yang dikonsumsi oleh siswa. Kaum muda tampaknya semakin sering merusak diri mereka dan orang lain, 
dan semakin tidak peduli untuk berkontribusi terhadap kesejahteraan sesama manusia.

Selain itu akibat kemajuan zaman rasa nasionalisme kaum muda mulai tergerus dan menjadi masalah bagi para siswa siswi yang masih dalam proses pertumbuhan dan penemuan jati diri. Ada beberapa kasus penyimpangan yang dilakukan generasi muda yang menunjukkan sudah memudarnya nilai nasionalisme, seperti diberitakan media beberapa waktu yang lalu tentang perilaku kaum muda yang tidak menhargai lambang negara dan bendera bangsa Indonesia.

Nasionalisme merupakan suatu hal yang sangatlah penting untuk dimiliki setiap individu agar dapat menjalin hubungan dengan negara sebaik mungkin. Nasionalisme sungguh sangatlah penting dimiliki sejak sedini mungkin agar dapat membentuk seorang individu yang sesuia dengan ciri - ciri warga negara yang baik. Selain itu nasionalisme mengandung nilai - nilai sendiri yang dapat membantu manusia menjalani kehidupan yang lebih baik. Seperti nilai kerjasama, rela berkorban, saling menghargai, bangga menjadi bangsa Indonesia, dan sebagainya. Penanaman nasionalisme tersebut dimulai dari sekolah formal agar dapat membentuk seorang individu yang memiliki sikap nasionalisme dalam diri peserta didik tersebut.

Untuk mencegah lebih parahnya krisis akhlak, upaya tersebut mulai dirintis melalui pendidikan karakter bangsa. Dalam pendidikan karakter bangsa di sekolah, penanaman nilai - nilai karakter diberikan secara terintegrasi di dalam proses pembelajaran pada mata pelajaran. Yang dimaksud dengan penanaman nilai karakter secara terintegrasi di dalam proses pembelajaran adalah dengan pengenalan nilai-nilai, fasilitas diperolehnya kesadaran akan pentingnya nilai nilai, dan penginternalisasian nilai-nilai ke dalam tingkah laku peserta didik seharihari melalui proses pembelajaran baik yang berlangsung di dalam maupun di luar kelas.

Salah satu mata pelajaran yang dapat membantu menanamkan nilai karakter adalah melalui pelajaran sejarah. Mata pelajaran sejarah telah diberikan pada tingkat pendidikan dasar sebagai bagian yang integral dari mata pelajaran IPS. Pada tingkat SD/MI sejarah dibicarakan dengan pendekatan estetis. Maksudnya adalah 
bahwa sejarah diberikan semata-mata untuk menanamkan rasa cinta kepada perjuangan, pahlawan, tanah air, dan bangsa. Untuk SMP/MTS sejarah lebih diberikan dengan pendekatan etis. Yakni untuk memberikan pemahaman tentang konsep hidup bersama sehingga selain memiliki rasa cinta kepada perjuangan, pahlawan, tanah air dan bangsa mereka tidak canggung dalam pergaulan masyarakat yang semakin majemuk (Kuntowijoyo, 1995:3-4). Menurut Said Hamid Hasan (dalam Suryadi,2012:77) untuk jenjang SMA, tujuan pendidikan sejarah sudah berkembang pada pemahaman mendalam sebagai peristiwa sejarah yang dianggap penting untuk membangun kemampuan berpikir kritis, kemampuan belajar, rasa ingin tahu, kepedulian sosial, dan semangat kebangsaan.

Pendidikan sejarah menjadi sesuatu yang sangat penting. Dimana proses pengembangan nilai-nilai yang menjadi landasan dari karakter itu menghendaki suatu proses yang berkelanjutan. Dalam mengembangkan pendidikan karakter bangsa, kesadaran akan siapa dirinya dan bangsanya adalah bagian yang teramat penting. Kesadaran tersebut dapat terbangun dengan baik melalui pendidikan sejarah yang memberikan pencerahan dan penjelasan mengenai siapa dirinya dan bangsanya di masa lalu yang menghasilkan dirinya dan bangsanya di masa kini.

Dalam pendidikan sejarah ada nilai-nilai yang dapat di wariskan dan ditanamkan, salah satunya adalah nilai nasionalisme. Dalam pendidikan sejarah, ada beberapa materi yang dapat dipelajari untuk menanamkan nilai nasionalisme, karena tujuan dari pendidikan sejarah salah satunya ialah untuk menanamkan sikap nasionalisme. Seperti pelajaran sejarah yang mengajarkan bagaimana meneladani perjuangan para pahlawan dalam usaha mempertahankan kemerdekaan Indonesia dari penjajah, hidup toleran dengan adanya berbagai macam suku, agama, ras, etnik, dan adat istiadat yang ada di Indonesia sehingga siswa menjadi manusia yang mempunyai semangat kebangsaan dam mencintai tanah air nya.

Pemerintah melalui Kementerian Pendidikan Nasional (KEMENDIKNAS) sejak tahun 2010 telah mencanangkan pendidikan karakter bagi semua tingkat pendidikan. Program ini diadakan karena selama ini dunia pendidikan Indonesia dinilai belum sepenuhnya berhasil dalam menghantarkan generasi bangsa menjadi pribadi - pribadi yang bermartabat. Dunia pendidikan Indonesia hanya mampu 
melahirkan lulusan dengan tingkat intelektualitas memadai. Namun, tidak sedikit diantara lulusan tersebut belum mempunyai perilaku yang cerdas serta mental kepribadian yang baik. Selain itu, pendidikan harus membangun pula kesadaran, pengetahuan, wawasan, dan nilai berkenaan dengan lingkungan tempat diri dan bangsanya hidup, nilai yang hidup di masyarakat, sistem sosial yang berlaku dan sedang berkembang.

Kemendiknas (2010:4) mengemukakan bahwa pendidikan karakter dimaknai sebagai pendidikan yang mengembangkan nilai- nilai karakter bangsa pada diri peserta didik sehingga mereka memiliki nilai dan karakter dalam dirinya kemudian akan menerapkan nilai - nilai tersebut dalam kehidupannya. Selanjutnya, pendidikan karakter bukan hanya sekedar mengajarkan mana yang benar dan mana yang salah, tetapi lebih merupakan suatu usaha menanamkan kebiasaan kebiasaan yang baik sehingga peserta didik mampu bersikap dan bertindak berdasarkan nilai- nilai yang telah menjadi kepribadiannya.

Secara formal, implementasi pendidikan karakter memiliki landasan yuridis yang kuat. Hal ini merujuk pada fungsi dan tujuan pendidikan nasional yang memberikan dasar bahwa pendidikan yang dilaksanakan selayaknya mengarah pada pembentukan karakter, dan penanaman nilai - nilai karakter bagi generasi muda bangsa. Dengan demikian, disamping menjadi langkah strategis dalam menangani persoalan krisis karakter yang sedang terjadi, implementasi pendidikan karakter yang disertai penanaman nilai - nilai karakter sesungguhnya merupakan amanah dari peraturan perundang - undangan. Sehingga dengan adanya permasalahan krisis karakter dapat dijadikan indikator bahwa implementasi penanaman nilai karakter belum terlaksana dengan optimal.

Penanaman nilai-nilai karakter pada peserta didik dinilai penting, agar peserta didik mampu bersaing, beretika, bermoral, sopan, santun dan berinteraksi dengan masyarakat. Kesuksesan seseorang tidak ditentukan semata-mata oleh pengetahuan dan kemampuan teknis (hard skill) saja, tetapi lebih oleh kemampuan mengelola diri dan orang lain (soft skill). Sehingga, penanaman nilai karakter pada pembelajaran sudah seharusnya diterapkan oleh guru kepada peserta didik. Berdasarkan uraian tersebut, peneliti tertarik untuk mengadakan sebuah penelitian 
dengan judul "Implemantasi Nilai Karakter Nasionalisme Melalui Pembelajaran Sejarah Materi Pendudukan Jepang di Indonesia di SMA Swasta Budisatrya Medan Kelas XI T.A 2018/2019”.

Metode yang digunakan dalam penelitian ini adalah metode penelitian deskriptif kualitatif. Penelitian deskriptif kualitatif adalah penelitian yang menggambarkan atau melukiskan objek penelitian berdasarkan fakta-fakta yang tampak atau sebagaimana adanya. Nawawi dan Martini (1996: 73).Penelitian deskriptif kualitatif berusaha mendeskripsikan seluruh gejala atau keadaan yang ada, yaitu keadaan gejala menurut apa adanya pada saat penelitian dilakukan.

Dalam penelitian ini, peneliti mengumpulkan data tanpa melakukan intervensi terhadap subjek penelitian. Peneliti juga tidak melakukan manipulasi atau memberikan pengaruh terhadap baik narasumber maupun aktivitas yang terjadi di lapangan. Dalam peneltian ini, data yang ingin dikumpulkan adalah data terkait implementasi penanaman nilai karakter Nasionalisme dalam pembelajaran sejarah di SMA Swasta Budisatrya Medan.

Dalam penelitian ini, penulis menggunakan observasi nonparticipant (nonpartisipasi). Dimana penulis tidak terlibat langsung dalam segala kegiatan yang dilakukan oleh subjek yang diteliti. Melainkan seorang penulis hanya sebagai pengamat, pencatat guna mengumpulkan data segala hal tentang yang terkait. Selanjutnya, dalam hal ini penulis melakukan observasi, penulis menyusun langkah-langkah awal yang sudah dilakukan. Untuk langkah pertama penulis memilih lokasi penelitian. Langkah selanjutnya, peneliti dapat mengamati kegiatan pembelajaran dengan mendapatkan informasi dari guru dan siswa. Agar sesuai hasil wawancara dengan kenyataan yang sebenarnya terjadi didalam kegiatan pembelajaran yang sudah diteliti. Hal yang menjadi fokus observasi dalam penelitian ini adalah pembelajaran dalam kelas hingga perilaku siswa setelah menerima pembelajaran dalam aktivitas didalam maupun diluar kelas.

Selanjutnya, teknik yang paling penting untuk mendapatkan data yang konkret yaitu dengan teknik wawancara dan Dokumentasi. 


\section{II.PEMBAHASAN}

Pemerintah melalui Kementerian Pendidikan Nasional (KEMENDIKNAS) sejak tahun 2010 telah mencanangkan pendidikan karakter bagi semua tingkat pendidikan. Program ini diadakan karena selama ini dunia pendidikan Indonesia dinilai belum sepenuhnya berhasil dalam menghantarkan generasi bangsa menjadi pribadi - pribadi yang bermartabat. Dunia pendidikan Indonesia dinilai hanya mampu melahirkan lulusan dengan tingkat intelektualitas memadai. Namun, tidak sedikit diantara lulusan tersebut belum mempunyai perilaku yang cerdas serta mental kepribadian yang baik. Selain itu, pendidikan harus membangun pula kesadaran, pengetahuan, wawasan, dan nilai berkenaan dengan lingkungan tempat diri dan bangsanya hidup, nilai yang hidup di masyarakat, sistem sosial yang berlaku dan sedang berkembang.

Kemendiknas (2010:4) mengemukakan bahwa pendidikan karakter dimaknai sebagai pendidikan yang mengembangkan nilai- nilai karakter bangsa pada diri peserta didik sehingga mereka memiliki nilai dan karakter dalam dirinya kemudian akan menerapkan nilai - nilai tersebut dalam kehidupannya. Selanjutnya, pendidikan karakter bukan hanya sekedar mengajarkan mana yang benar dan mana yang salah, tetapi lebih merupakan suatu usaha menanamkan kebiasaan - kebiasaan yang baik sehingga peserta didik mampu bersikap dan bertindak berdasarkan nilainilai yang telah menjadi kepribadiannya.

Secara formal, implementasi pendidikan karakter memiliki landasan yuridis yang kuat. Hal ini merujuk pada fungsi dan tujuan pendidikan nasional yang memberikan dasar bahwa pendidikan yang dilaksanakan selayaknya mengarah pada pembentukan karakter, dan penanaman nilai - nilai karakter bagi generasi muda bangsa. Dengan demikian, disamping menjadi langkah strategis dalam menangani persoalan krisis karakter yang sedang terjadi, implementasi pendidikan karakter yang disertai penanaman nilai - nilai karakter sesungguhnya merupakan amanah dari peraturan perundang - undangan. Sehingga dengan adanya permasalahan krisis karakter dapat dijadikan indikator bahwa implementasi penanaman nilai karakter belum terlaksana dengan optimal. 
Penanaman nilai-nilai karakter pada peserta didik dinilai penting, agar peserta didik mampu bersaing, beretika, bermoral, sopan, santun dan berinteraksi dengan masyarakat. Kesuksesan seseorang tidak ditentukan semata-mata oleh pengetahuan dan kemampuan teknis (hard skill) saja, tetapi lebih oleh kemampuan mengelola diri dan orang lain (soft skill). Sehingga, penanaman nilai karakter pada pembelajaran sudah seharusnya diterapkan oleh guru kepada peserta didik, seperti yang terlaksana di SMA Swasta Budisatrya Medan.

Seperti yang sudah dijelaskan sebelumnya bahwasannya nasionalisme merupakan hal yang perlu dimiliki dan dikembangkan sedini mungkin. Nilai karakter nasionalisme harus dimiliki setiap generasi muda terutama siswa siswi di tingkat sekolah, agar dapat menjalin hubungan yang baik dengan sesama dan masyarakat agar tidak terjadi perpecahan dan pemberontakan dalam kehidupan sehari -hari . Membentuk karakter siswa agar menjadi seorang yang nasionalis dapat dibentuk melalui kegiatan non formal seperti dalam keluarga, teman sebaya serta perkumpulan - perkumpulan lingkungan. Selain itu bisa juga dibentuk melalui pendidikan formal seperti melakukan kegiatan pembelajaran di sekolah. Dengan demikian maka setiap sekolah diharapkan dapat menjadi wadah untuk mewujudkan tujuan pendidikan nasional Indonesia. Pendidikan formal di sekolah dapat membantu membentuk karakter nasionalisme siswa lewat proses pembelajaran didalam kelas serta kegiatan - kegiatan diluar jam belajar kelas. Guru dapat menjadi fasilitator untuk membantu membentuk dan mengembangkan karakter siswa lewat materi pelajaran pelajaran yang dibawakan.

Dalam hal ini mata pelajaran sejarah dianggap sebagai salah satu mata pelajaran yang dapat membantu membentuk dan mengembangkan karakter nasionalisme siswa lewat materi yang dibawakan, salah satunya seperti materi Pendudukan Jepang di Indonesia yang disajikan pada semester genap dalam tingkatan pendidikan SMA kelas XI.

Berdasarkan analisa peneliti, dalam materi tersebut selain menggambarkan tentang kehidupan dan perjuangan bangsa Indonesia memperjuangkan kemerdekaan, secara tersirat memberikan pesan bahwa rasa dan jiwa nasionalisme diperlukan untuk mempertahankan keutuhan bangsa Indonesia. Hal ini dapat 
diketahui berdasarkan pengamatan dan wawancara yang dilakukan dengan guru sejarah dan siswa. Guru sejarah berusaha membentuk rasa nasionalisme siswa melalui materi tersebut dengan menggunakan RPP yang telah dirancang sebelumnya. Kegiatan - kegiatan dalam rancangan RPP disesuaikan dengan kegiatan - kegiatan yang menggambarkan usaha mencapai nilai -nilai dari nasionalisme itu sendiri. Seperti, kegiatan menyanyikan lagu wajib nasional sebelum memulai pembelajaran, membentuk kelompok diskusi untuk memecahkan masalah dalam proses pembelajran serta menjaga kebersihan lingkugan sekitar ruang kelas. Hasilnya, siswa dapat bekerja sama antara yang satu dengan yang lain, menghargai perbedaan antar siswa, serta mempunyai rasa tanggung jawab untuk menjaga kebersihan lingkungannya sebagai bagian dari usaha menjaga keutuhan lingkungan yang merupakan nilai dari karakter nasionalisme.

Selain kegiatan didalam kelas, guru juga menyarankan kepada siswa untuk mengikuti kegiatan ekstrakurikuler yang disediakan oleh sekolah yang tentunya mendukung perkembangan nasionalisme siswa seperti kegiatan baris berbaris, paskibra, dan pramuka. Selain melalui kegiatan pembelajaran dalam kelas yang dilakukan oleh guru (terutama guru sejarah), sekolah dinilai juga ikut mendukung perkembangan karakter nasionalisme siswa dengan merayakan upacara serta perayaan hari besar nasional. Hal ini didukung oleh hasil wawancara serta dokumentasi - dokumentasi yang didapat baik secara pribadi atau dokumentasi sekolah.

Kendala yang dihadapi oleh guru dalam membentuk karakter siswa cenderung berasal dari luar diri siswa seperti waktu, lingkungan serta media elektronik yang sering digunakan siswa. Menurut analisa peneliti ketiga hal tersebut memiliki keterkaitan satu dengan yang lain sebagai berikut.

Waktu wajib belajar bagi siswa melalui forum sekolah adalah 12 tahun dengan melewati 3 tingkatan. Sekolah Dasar (SD) 6 tahun, Sekolah Menengah Pertama (SMP) 3 tahun, Sekolah Menengah Atas (SMA) atau Sekolah Menengah Kejuruan (SMK) 3 tahun. Waktu yang terbatas bagi sekolah dan guru - guru dalam menanamkan dan membentuk karakter siswa merupakan salah satu kendala yang dihadapi. Dengan waktu yang terbatas disekolah maka interaksi antara guru dan 
siswa juga terbilang terbatas, sehingga siswa akan lebih banyak menghabiskan watu dengan lingkungan keluarga, lingkungan teman sebaya, dan lingkungan masyarakat.

Karena siswa dengan lingkungan lebih memiliki waktu yang banyak untuk melakukan interaksi maka peranan orang tua sebagai pembentuk dan pengawas pergaulan siswa diperlukan. Dengan terbentuknya karakter yang tercipta di lingkungan hal ini akan berpengaruh pada siswa di sekolah. Apabila siswa sudah mempunyai karakter yang baik maka tugas guru hanya tinggal melanjutkan saja, hal ini didukung oleh wawancara yang dilakukan dengan GS. Namun, apabila karakter yang dibawa oleh siswa ke sekolah kurang baik bahkan buruk maka sekolah harus berusaha kembali membentuk karakter siswa tersebut.

Orang tua juga berperan mengawasi siswa dalam penggunaan media elektronik yang digunakan siswa dalam kehidupan sehari - hari, baik dalam menonton acara televisi maupun penggunaan handphone dalam bersosialisasi dan mendapatkan informasi. Tontonan yang menunjukkan kekerasan dan pemberontakan akan memberikan pengaruh kepada siswa untuk menjadi seorang pemberontak juga. Dengan demikian maka siswa akan memilki sifat sebagai perusuh dan pembuat onar. Apabila hal ini terus berlanjut dalam jangka waktu yang panjang maka siswa tidak akan memiliki karakter nasionalisme, dan akan menyebabkan terjadinya ketidak saling menghargai dalam kehidupan bersosial siswa baik dengan masyarakat bahkan dengan lingkungan.

Berdasarkan hasil pengamatan dan wawancara yang dilakukan oleh peneliti maka dapat diketahui SMA Swasta Budisatrya Medan telah mengimplementasikan sebagian besar nilai karakter nasionalisme baik didalam kelas maupun diluar kelas. Hal ini diketahui berdasarkan persiapan guru dalam melakukan persiapan pembelajaran, pelaksanaan pembelajaran, serta evaluasi hasil yang dilakukan baik dalam kegiatan belajar dalam kelas dan luar kelas yang sudah hampir memenuhi beberapa indikator yang ditentukan dalam instrument observasi penelitian yang disusun sebelum penelitian berlangsung. 


\section{III.PENUTUP}

Persiapan pembelajaran yang dilakukan oleh guru sejarah dalam kegiatan belajar didalam kelas disusun kedalam bentuk RPP yang didalamnya sudah dituliskan mengenai nilai karakter yang diambil melalui materi pelajaran tersebut. Selain itu, didalam RPP juga dicantumkan kegiatan - kegiatan yang membantu untuk membentuk siswa memiliki nilai karakter nasionalisme dan dapat melaksanakan dalam kehidupan sehari - harinya.

Pelaksanaan pembelajaran dalam kelas yang dilakukan guru sejarah sudah berdasarkan RPP yang disusun sehingga sebagian tujuan dari pembelajaran tersebut yaitu untuk membentuk nilai karakter nasionalisme dalam diri siswa dapat tercapai. Hal ini dilihat melalui aktivitas yang dilakukan saat pembelajaran dimulai, metode pembelajaran yang dilakukan guru saat kegiatan inti, serta evaluasi yang dilakukan setiap selesei melakukan pembelajaran. Selain itu, pembentukan dan penanaman nasionalisme pada siswa didukung lewat kegiatan ekstrakurikuler yang diselenggarakan disekolah.

Berdasarakan indikator yang digunakan oleh peneliti yaitu : (a. dapat melakukan kerjasama yang baik dengan orang - orang disekitarnya; (b. dapat menghargai setiap perbedaan yang ada dalam masyarakat seperti suku, ras,agama,dsb; (c. memiliki rasa bangga terhadap Negara serta menempatkan kepentingan bersama diatas kepentingan sendiri. Dapat diketahui bahwa Siswa/i di SMA Swasta Budisatrya Medan sebagian besar telah memiliki nasionalisme dalam diri mereka. Hal ini ditunjukkan selama kegiatan pembelajaran di kelas berlangsung dan kegiatan diluar kelas. Siswa/i hampir memenuhi semua indikator seseorang yang dikatakan bernasionalisme sesuai dengan instrument observasi yang telah disusun seperti, bisa bekerja sama satu dengan yang lain, saling menghargai sesama, bangga menjadi warga Indonesia, serta merasa bertanggung jawab untuk menjaga kebersihan, kerapihan, keutuhan lingkungan sekitarnya.

Kendala yang dihadapi oleh guru saat melaksanakan pembelajaran sejarah untuk memebentuk dan menanamkan nilai nasionalisme bagi siswa di SMA Swasta Budisatrya Medan, meliputi : waktu, linkungan, dan media elektronik adalah sebagai berikut : 
Waktu, sekolah hanya mempunyai waktu kurang dari 3 tahun untuk membentuk karakter anak yang begitu banyaknya dan bervariasi sedangkan pelajaran sejarah mempunyai jam terbang yang terbatas, hal ini sangat menghambat selain materi pelajaran sejarah itu sendiri juga pelaksanaan pendidikan karakter itu sendiri.

Faktor lingkungan baik keluarga maupun masyarakat akan mempengaruhi perkembangan perilaku dan kepribadian anak karena anak labih banyak menghabiskan waktu bersama keluarga sebelum dia siap untuk bersosialisasi dengan masyarakat dan masyarakat sangat mempengaruhi karakter anak begitu dia mulai bersosialisasi dengan masyarakat disekitarnya.

Media elektronik, pada zaman yang modern dan semakin canggih ini mempengaruhi keadaan siswa bahkan seluruh kalangan masyarakat.

\section{REFERENSI}

Dharma Kesuma. (2012). Pendidikan Karakter Kajian Teori dan Praktik di Sekolah. Bandung: PT Remaja Rosdakarya.

E. Mulyasa. (2009). Praktik Penelitian Tindakan Kelas. Bandung: Rosdakarya.

Isjoni. (2007). Cooperative Learning: Efektifitas Pembelajaran Kelompok. Bandung: Alfabeta.

Kuntowijoyo. (1995). Pengantar Ilmu Sejarah. Yogyakarta: Bentang Budaya.

Lickona, Thomas. (2013). Pendidikan Karakter: Panduan Lengkap Mendidik Siswa Menjadi Pintar dan Baik. Bandung: Penerbit Nusa Media.

Moleong, j, Lexy. (2006). Metodologi Penelitian Kualitatif. Bandung: PT. Remaja Rosdakarya.

Mulyasa. (2011). Manajemen Berbasis Sekolah, Konsep, strategi dan Implementasi. Bandung : PT Remaja Rosdakarya.

Prayitno. (2010). Layanan Bimbingan Kelompok dan Konseling Kelompok. Universitas Negeri Padang

Sanjaya, Wina.(2008). Perencanaan dan desain sistem pembelajaran. Jakarta: Kencana Prenada Media Group. 